\title{
Application of AHP in the Bank Stock's Investment Selection
}

\author{
Li Hua \\ Institute of Quantitative \&Technical Economics, Chinese \\ Academy of Social Sciences, Beijing, China \\ School of Business Administration, University of Science \\ and Technology Liaoning, Anshan, China \\ E-mail:14581579@qq.com
}

\author{
Dou Shi-ting \\ School of Business Administration \\ University of Science and Technology Liaoning \\ Anshan, China \\ E-mail: 1196195469@qq.com
}

\begin{abstract}
On the basis of the theory of investment, with the Banks in China for examples, this paper selects the method of Analytic Hierarchy Process to analyze the bank's financial indicators and non-financial indicators, through calculating their profitability, debt paying ability, capacity development and other indicators' comprehensive weight, points out the most worthwhile investment bank, and provides a reference for bank-stock investors .
\end{abstract}

Keywords-analytic hierarchy process; Bank stock; investment Selection

\section{INTRODUCTION}

In March 2011 the level of profitability has been restored to its level in 2008 which is the global financial crisis. In the post financial-crisis era,the global economy recoveries gradually, and the major stock indexes as barometers are out of the bottom. Under the condition of steady development of the global economy, the stock market is in the direction of more standardized, more stable.Stock investment' income is bigger but the risk is higher related to other types of investment funds.But the Bank stock investment has better security because of its investment main bodies are banks.So bank stock is the best choice,Especially under the background of that countries is taking measures to regulate banks market and the stock market.

Barbara C, Philip m. detected the bank stock performance into six aspects with camels rating system ${ }^{[1]}$. Andre Uhde, Ulrich Heimeshoff using the entire European Union Banks' balance sheets data showed that the Banks had a certain relationship with financial stability ${ }^{[2]}$. DP Louzis, AT Vouldis, VL Metaxas using the regression analysis proved that the country's macroeconomic factors had an impact on banking stocks ${ }^{[3]}$. Chen $\mathrm{S}$ shown that the market-valued capital ratio could indeed serve as a strong predictive indicator for bank's share performance during the financial crisis in the late $1990 \mathrm{~s}^{[4]}$. Necmi k. Avkiran analyzed Banks' financial ratios by the method of data envelopment analysis (DEA ${ }^{[5]}$, .Roberta, b. Staub, Geraldo da Silva e Souza, Benjamin m. Tabak analyzed that the Brazil bank' high technical inefficiency was the cause of macroeconomic fluctuations by $\mathrm{DEA}^{[6]}$. Necmi k. Avkiran, Hiroshi Morita analyzed and simulated the ranking of Japanese bank stock market with the method of generalizing data envelopment analysis ${ }^{[7]}$. Meryem Duygun Fethi, Fotios Pasiouras studied the performance efficiency of banks with operations research and artificial intelligence techniques, and thus provided the basis for the investment option ${ }^{[8]}$. Y. H. Che n, S. C. Chen, C. L. Tsay put forward using the balanced scorecard and analytic hierarchy process (AHP) to construct the best investment strategy of bank stock $^{[9]}$. Chen Jiali, Li Xuejian analyzed 14 listed Banks stock's value by using the principal component analysis and analytic hierarchy process $(\mathrm{AHP})^{[10]}$.Yu Jie analyzed the investment value of ICBC and China Construction Bank from the perspective of financial and management benefit, the conclusion pointed out that the ICBC was more valuable ${ }^{[11]}$. Lu Pugui analyzed the Banks invest value by AHP,and proved that China Merchants Bank is the most competitive and the most valuable $\operatorname{Bank}^{[12]}$.

This article selects the analytic hierarchy process (AHP) as the research method,chooses the more comprehensive financial indicators such as profitability, development ability and debt paying ability, and some of the non-financial indicators as the standard, and researches the investment choice of Chinese Banks.This paper introduced the development of the international market situation first, then analyzed the influence factors of investment Banks and index selection, then analyzed the comprehensive weights and the comprehensive ranking of the Banks bye AHP, finally drew the conclusion.

\section{INFLUENCE FACTORS OF CHOOSING BANKING STOCK}

Professional investors always consider the bank's financial indicators and business performance when they make investment decisions,but throughout the domestic and foreign articles few analyzed the invest value of the bank stock. In the index selection, this paper creatively chose the specific financial indicators, the bank itself and the national macro factors, it is more comprehensive and reliable. Because of the characteristic of the bank, it doesn't need operation ability, so this paper choose the profitability, debt paying ability, developing capability and other indicators to analyze bank stock's value.

Profitability refers to the enterprise's profit ability, and usually characterized by the amount of the business income and its level in a certain period.Specific indicators include the total assets return rate, the rate of return on net assets and the sales gross margin.

Debt paying ability refers the enterprise's ability of using its assets to repay the long-term debt and short-term debt. Specific indicators are asset-liability ratio and equity ratio.

Enterprise's development ability refers to the ability of expanding its scale, and the potential ability of growing power. Specific indicators include total assets growth rate, growth rate of net assets, net profit growth rate.

In addition to financial indicators, residential investors would consider more other indicators. Then control investors' choices is not just the financial ratio indicators. This paper chooses the bank's profile and the credit risk and the risk of the change of policy.

\section{BANK STOCK INVESTMENT ANALYSIS WITH AHP}

Analytic hierarchy process (AHP), is founded by Thomas Saatv who is an American operational researcher in the early 
1970's.Its peculiar advantages such as systemic, concise and practical, and can handle bulk data become an important research method.

\section{A. Establish a class hierarchy}

In bank stock's investment selection, in order to get the best benefit, select indicators which may be considered by an investor as the rule layer to analysis, determine the hierarchical structure as follows:

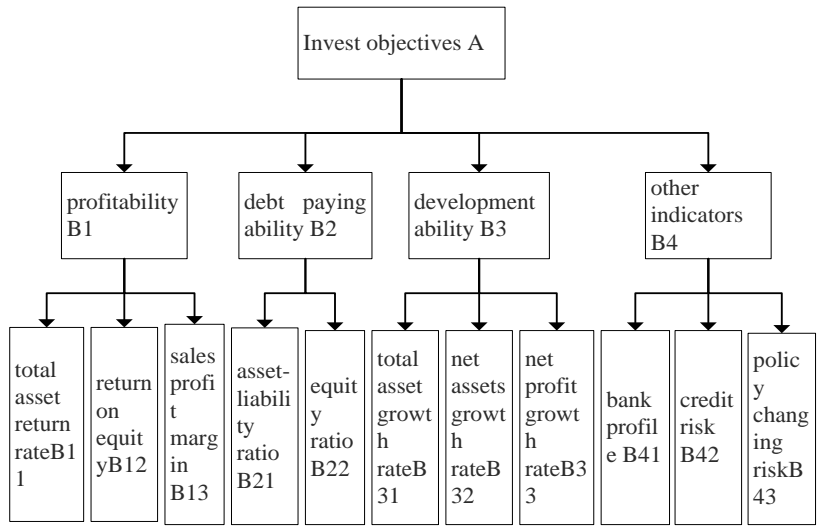

Fig.1 hierarchical structure

Scheme layer:M1:the bank of China(BOC);M2:China construction bank M2(CCB); M3: industrial and commercial bank of China(ICBC);M4:China merchants bank(CMB); M5:Shanghai pudong development bank (SPDB).

\section{B. Building judgment matrix, single level sorting and consistency check}

This paper takes the method of expert scoring, and 10 experts scores including financial company's top managers, experienced and effective investors. The grading standard is the proportion of nine points scale (shown below), first introducing the grading standard to those experts, and then we should remove a highest and a minimum point for accuracy, averaging and then get the judgment matrix.

TABLE 1 PROPORTION OF NINE POINTS SCALE

\begin{tabular}{cl}
$\begin{array}{c}\text { Important } \\
\text { dimensions }\end{array}$ & \multicolumn{1}{c}{ Meaning } \\
\hline 1 & two factors are equally important \\
3 & i factor is more important than $\mathrm{j}$ factor slightly \\
5 & i is more important than $\mathrm{j}$ factor \\
7 & i is very important than $\mathrm{j}$ factor \\
9 & i is extremely important than $\mathrm{j}$ factor \\
$2,4,6,8$ & among the above grade scale value of the state \\
reciprocal & If $\mathrm{j}$ and i compare, the judgment of the value is $1 /$ aij
\end{tabular}

After getting the judgment matrix,then we should calculate the weight with the method of sum. First normalize the judgment matrix, which we should make each number in the box matrix divided by the sum of its column and get a normalized matrix. Then make each row in addition, divide order number to get the variable weights $W$. Consistency check the judgment matrix, and first obtain the biggest characteristic root $\lambda \max$, where:

$$
\lambda \max =\frac{1}{n} \sum_{i=1}^{n} \frac{(A w)_{i}}{w_{i}},
$$

Then find the consistency index $C I$, where:

$$
C I=\frac{\lambda \max -n}{n-1} .
$$

Considering the consistency deviation causes may also be random causes, so we should test the judgment matrix whether is satisfied or not, we still need to compare $C I$ and the mean random consistency index $R I$ (shown below).

TABLE 2 THE AVERAGE RANDOM CONSISTENCY INDEX

\begin{tabular}{|l|l|l|l|l|l|l|}
\hline Order number & 1 & 2 & 3 & 4 & 5 & 6 \\
\hline$R I$ & 0 & 0 & 0.52 & 0.89 & 1.12 & 1.26 \\
\hline
\end{tabular}
pass the test.where:

$$
C R=\frac{C I}{R I} .
$$

According to the above methods, first the expert scoring results is in the following table:

TABLE 3 PRIMARY INDEX JUDGMENT MATRIX

\begin{tabular}{|c|l|c|c|c|}
\hline & $\begin{array}{l}\text { Profitabi } \\
\text { lity B1 }\end{array}$ & $\begin{array}{l}\text { Debt paying } \\
\text { abilityB2 }\end{array}$ & $\begin{array}{l}\text { Developmen } \\
\text { t ability B3 }\end{array}$ & $\begin{array}{l}\text { other } \\
\text { indicators } \\
\text { B4 }\end{array}$ \\
\hline B1 & 1 & 1.166 & 0.913 & 0.985 \\
\hline B2 & 0.858 & 1 & 0.815 & 0.885 \\
\hline B3 & 1.095 & 1.227 & 1 & 1.02 \\
\hline B4 & 1.015 & 1.13 & 0.98 & 1 \\
\hline
\end{tabular}

Then we should normalize the elements of each column of the result, the formula is

$$
C i j=\frac{C i j}{\sum C i j},
$$

Then we calculate the sum of each row and then divided by the number 4 , get the weight vector w: $\left(\begin{array}{lll}0.252 & 0.252 & 0.270\end{array}\right.$ 0.221 ).

The next checking for consistency, first of all get the biggest characteristic root $\lambda \max =4.000568$, then calculate $C I=0.000189, C R=0.000213<0.1$, the results pass the test, so obtain satisfactory consistency.

Then we can calculate the weight of the secondary index vector and consistency test. The results are as follows:

TABLE 4 THE PROFITABILITY JUDGMENT MATRIX AND RESULT

\begin{tabular}{|c|c|c|c|c|}
\hline & $\begin{array}{l}\text { total assets } \\
\text { return rate } \\
\text { B11 }\end{array}$ & $\begin{array}{l}\text { return on } \\
\text { equity B12 }\end{array}$ & $\begin{array}{l}\text { sales profit } \\
\text { margin } \\
\text { B13 }\end{array}$ & w \\
\hline $\mathrm{B} 11$ & 1 & 0.747 & 1.582 & 0.341 \\
\hline $\mathrm{B} 12$ & 1.339 & 1 & 1.764 & 0.430 \\
\hline $\mathrm{B} 13$ & 0.632 & 0.567 & 1 & 0.229 \\
\hline$\lambda_{\text {max }=3.015,} C I$ \\
$=$
\end{tabular}


TABLE 5 DEBT PAYING ABILITY JUDGMENT MATRIX AND RESULT

\begin{tabular}{|l|l|c|c|}
\hline & $\begin{array}{l}\text { asset-liability ratio } \\
\text { B21 }\end{array}$ & equity ratio B22 & w \\
\hline $\mathrm{B} 21$ & 1 & 0.935 & 0.483 \\
\hline $\mathrm{B} 22$ & 1.070 & 1 & 0.517 \\
\hline$\lambda_{\max =2,} \mathrm{CI}$ & & \\
\hline
\end{tabular}

TABLE 6 DEVELOPMENT ABILITY JUDGMENT MATRIX AND RESULT

\begin{tabular}{|c|c|c|c|c|}
\hline & $\begin{array}{l}\text { Total asset } \\
\text { growth rate } \\
\text { B31 }\end{array}$ & $\begin{array}{l}\text { net assets } \\
\text { growth rate } \\
\text { B32 }\end{array}$ & $\begin{array}{l}\text { Net profit } \\
\text { growth rate } \\
\text { B33 }\end{array}$ & $\mathbf{w}$ \\
\hline B31 & 1 & 0.819 & 1.012 & 0.312 \\
\hline B32 & 1.221 & 1 & 1.145 & 0.372 \\
\hline B33 & 0.988 & 0.873 & 1 & 0.316 \\
\hline
\end{tabular}

TABLE 7 OTHER INDICATORS JUDGMENT MATRIX AND RESULT

\begin{tabular}{|l|l|c|c|c|}
\hline & $\begin{array}{l}\text { bank } \\
\text { profile B41 }\end{array}$ & $\begin{array}{l}\text { credit risk } \\
\text { B42 }\end{array}$ & $\begin{array}{l}\text { the policy } \\
\text { changing risk } \\
\text { B43 }\end{array}$ & w \\
\hline B41 & 1 & 0.895 & 0.755 & 0.291 \\
\hline B42 & 1.117 & 1 & 1.158 & 0.362 \\
\hline B43 & 1.325 & 0.864 & 1 & 0.347 \\
\hline$\lambda_{\text {max }=3.011369, \quad C I}=0.005684512$, & $C R=0.010931754<0.1$ \\
\hline
\end{tabular}

According to the results, we can calculate the comprehensive weight of the component layer related to the elements and the total target, the formula is as follows:

$w=w_{1} \times w_{2}$, ( where $^{w_{1}}$ is the primary index weights in the total target, $w_{2}$ is the secondary index weights in the primary index).

The results are as follows:

TABLE 8 COMPREHENSIVE EVALUATION INDEX WEIGHT

\begin{tabular}{|c|c|c|}
\hline Elements layer & Child elements layer & $\begin{array}{l}\text { comprehensiv } \\
\text { e weight }\end{array}$ \\
\hline \multirow{3}{*}{ profitability: 0.252} & $\begin{array}{l}\text { total assets return rate : } \\
0.341\end{array}$ & 0.086 \\
\hline & return on equity: 0.430 & 0.108 \\
\hline & sales profit margin: 0.229 & 0.058 \\
\hline \multirow{2}{*}{$\begin{array}{c}\text { debt paying } \\
\text { ability: } 0.221\end{array}$} & asset-liability ratio: 0.483 & 0.107 \\
\hline & equity ratio: 0.517 & 0.114 \\
\hline \multirow{3}{*}{$\begin{array}{l}\text { development } \\
\text { ability: } 0.270\end{array}$} & $\begin{array}{l}\text { Total assets growth rate: } \\
0.312\end{array}$ & 0.084 \\
\hline & $\begin{array}{l}\text { net assets growth rate : } \\
0.372\end{array}$ & 0.100 \\
\hline & $\begin{array}{l}\text { net profit growth rate : } \\
0.316\end{array}$ & 0.085 \\
\hline \multirow{3}{*}{$\begin{array}{c}\text { other } \\
\text { indicators: } 0.257\end{array}$} & bank profile: 0.291 & 0.075 \\
\hline & credit risk : 0.362 & 0.093 \\
\hline & policy changing risk: 0.347 & 0.089 \\
\hline
\end{tabular}

From the graph we can see that in the first-level indicators the development ability is the most important indication.The following is the non-financial indicators.Then is the profitability. The debt paying ability is also one of the consideration factors.

\section{Analysis of bank stock with AHP}

Once again, hierarchy analysis is carried out on the Bank stock. Banks' financial ratios can be directly checked, but the other indicators are some qualitative indexes. We can't get data directly, so we use the above expert scoring method to calculate the weight of the Banks. The result is as follows:

TABLE 9 OTHER INDICATORS OF THE BANKS

\begin{tabular}{lcccc}
\hline & $\begin{array}{l}\text { bank } \\
\text { profile }\end{array}$ & $\begin{array}{l}\text { credit } \\
\text { risk }\end{array}$ & $\begin{array}{l}\text { policy } \\
\text { changing risk }\end{array}$ & $\begin{array}{l}\text { comprehensive } \\
\text { weight }\end{array}$ \\
\hline BOC & 0.2187 & 0.2066 & 0.2028 & 0.2088025 \\
CCB & 0.2175 & 0.2074 & 0.2013 & 0.2082224 \\
ICBC & 0.2197 & 0.2094 & 0.2027 & 0.2100724 \\
CMB & 0.1743 & 0.1879 & 0.1974 & 0.1872389 \\
SPDB & 0.1698 & 0.1887 & 0.1958 & 0.1856638 \\
\hline
\end{tabular}

These financial indicators data of the banks can be got directly, so we can directly calculate the comprehensive weights. This article will be subject to sina finance and economics of online data as the standard and choose the third quarter of 2013 financial data, specific as follows:

TABLE 10 BANKS' FINANCIAL DATA

\begin{tabular}{|c|c|c|c|c|c|c|c|c|}
\hline & \multicolumn{3}{|c|}{ profitability } & \multicolumn{2}{|c|}{$\begin{array}{l}\text { debt paying } \\
\text { ability }\end{array}$} & \multicolumn{3}{|c|}{ development ability } \\
\hline & B11 & $B 12$ & $B 13$ & $B 21$ & $B 22$ & B31 & B32 & B33 \\
\hline $\mathrm{BOC}$ & $\begin{array}{l}0.9 \\
2\end{array}$ & $\begin{array}{l}52.9 \\
4\end{array}$ & $\begin{array}{l}13.5 \\
4\end{array}$ & $\begin{array}{l}93.2 \\
1\end{array}$ & $\begin{array}{l}1371 \\
.90\end{array}$ & 6.91 & $\begin{array}{l}11.8 \\
3\end{array}$ & 12.47 \\
\hline $\mathrm{CCB}$ & $\begin{array}{l}1.1 \\
8\end{array}$ & $\begin{array}{l}60.3 \\
0\end{array}$ & $\begin{array}{l}16.8 \\
5\end{array}$ & $\begin{array}{l}93.0 \\
0\end{array}$ & $\begin{array}{l}1328 \\
.70\end{array}$ & $\begin{array}{l}12.7 \\
8\end{array}$ & $\begin{array}{l}14.3 \\
8\end{array}$ & 11.57 \\
\hline $\mathrm{ICBC}$ & $\begin{array}{l}1.1 \\
0\end{array}$ & $\begin{array}{l}59.7 \\
5\end{array}$ & $\begin{array}{l}16.6 \\
9\end{array}$ & $\begin{array}{l}93.4 \\
1\end{array}$ & $\begin{array}{l}1417 \\
.14\end{array}$ & 7.89 & $\begin{array}{l}14.8 \\
9\end{array}$ & 10.80 \\
\hline $\mathrm{CMB}$ & $\begin{array}{l}1.0 \\
2\end{array}$ & $\begin{array}{l}53.4 \\
1\end{array}$ & $\begin{array}{l}15.3 \\
6\end{array}$ & $\begin{array}{l}93.3 \\
8\end{array}$ & $\begin{array}{l}1410 \\
.21\end{array}$ & $\begin{array}{l}23.5 \\
6\end{array}$ & $\begin{array}{l}34.7 \\
3\end{array}$ & 13.51 \\
\hline SPDB & $\begin{array}{l}0.8 \\
3\end{array}$ & $\begin{array}{l}53.9 \\
6\end{array}$ & $\begin{array}{l}15.2 \\
3\end{array}$ & $\begin{array}{l}94.4 \\
8\end{array}$ & $\begin{array}{l}1711 \\
.45\end{array}$ & $\begin{array}{l}14.3 \\
8\end{array}$ & $\begin{array}{l}15.6 \\
2\end{array}$ & 14.35 \\
\hline
\end{tabular}

(Source: sina finance and economics network)

According to the above data, we can get the final comprehensive weight of each bank. The specific method is to normalize the indexes, and then multiplied by the corresponding proportion,after getting the weight coefficients of level indicator, we calculate the final comprehensive weight according to the level index weight coefficients. The result is in the following table:

TABLE 11 COMPREHENSIVE WEIGHT OF THE BANKS

\begin{tabular}{lllllll}
\hline & $\begin{array}{l}\text { profit } \\
\text { abilit } \\
\text { y }\end{array}$ & $\begin{array}{l}\text { Debt } \\
\text { paying } \\
\text { ability }\end{array}$ & $\begin{array}{l}\text { develop } \\
\text { ment } \\
\text { ability }\end{array}$ & $\begin{array}{l}\text { Other } \\
\text { indicato } \\
\text { rs }\end{array}$ & $\begin{array}{l}\text { compre } \\
\text { hensive } \\
\text { weight }\end{array}$ & $\begin{array}{l}\text { ranki } \\
\text { ng }\end{array}$ \\
\hline BOC & 0.12 & 0.19 & 0.14 & 0.21 & 0.17 & 5 \\
CCB & 0.22 & 0.19 & 0.18 & 0.21 & 0.20 & 2 \\
ICBC & 0.22 & 0.20 & 0.15 & 0.21 & 0.19 & 4 \\
CMB & 0.20 & 0.20 & 0.32 & 0.19 & 0.23 & 1 \\
SPDB & 0.18 & 0.22 & 0.20 & 0.19 & 0.20 & 3 \\
\hline
\end{tabular}




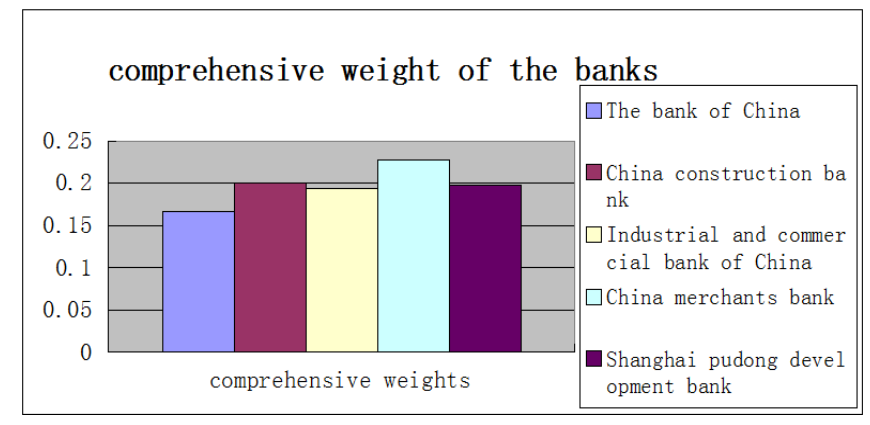

Fig.2 comprehensive weight of the banks

According to the result of the above analysis, we can see the comprehensive situation of the Banks. The bank of China is the last, its profitability and development ability are relatively backward, the others are not outstanding,so it is relatively backward.China Merchants Bank's other indicators are not very outstanding, but because of its good development ability,balanced profit ability, and debt paying ability, it is the most worthy of investment Bank.

\section{Some Limitations}

There are some limitations in this paper when choosing the analytic hierarchy process analysis, which may cause some different results. First of all, the expert scoring method is subjective, which may lead to the deviation of the objective fact, and cause the deviation of the results. Secondly, the indicators of this paper is part of the financial indicators, and the non-financial indicators select the profile, credit risk and policy changing risk, these indicators are only part of the comprehensive situation, which cannot represent the whole story of the bank. And these indicators may not be the focus when they invest for some people, thus may cause the deviation of the result.

\section{CONCLUSION}

From the above research, we have got the following conclusions:

Firstly, in the first-level indicators, the weights according to the sequence are the development ability, profit ability, debt paying ability, and other indicators.

Secondly, from the five Banks, the final comprehensive weight from the first to the end is China Merchants Bank, China Construction Bank, Shanghai Pudong Development Bank, Industry and Commercial Bank of China and Bank of China;so when we invest bank stocks, the best bank is China Merchants bank.

\section{ACKNOWLEDGMENT}

The authors would like to thank for the support by Natural Science Foundation of China under the Grant 71371092 and 71301015. The authors also thank for the support by Outstanding Young Scholars Growth Plan of Liaoning University under the Grant LJQ2011010

\section{REFERENCES}

[1] Barbara C, Philip M.A comparative study of efficiency in European banking [J]. Taylor an Francis Journals, 2003 ,35(17):1865-1876.

[2] Andre Uhde,Ulrich Heimeshoff. Consolidation in banking and financial stability in Europe: Empirical evidence[J]. Journal of Banking \& Finance. 2009, 33(7): 1299-1311.
[3] DP Louzis, AT Vouldis, VL Metaxas . Macroeconomic and bank-specific determinants of non-performing loans in Greece: A comparative study of mortgage, business and consumer loan portfolios [J]. Journal of Banking \& Finance, 2012,36(4) : 1012-102.

[4] Chen S. Capital ratios and the cross-section of bank stock returns: Evidence from Japan[J]. Journal of Asian Economics, 2011, 22(2): 99-114.

[5] Necmi K. Avkiran. Association of DEA super-efficiency estimates with financial ratios: Investigating the case for Chinese banks[J].Omega.2011,39(3):323-334.

[6] Roberta B. Staub,Geraldo da Silva e Souza,Benjamin M. Tabak 。 Evolution of bank efficiency in Brazil: A DEA approach[J].European Journal of Operational Research.2010,202(1) : 204-213.

[7] Necmi K. Avkiran, Hiroshi Morita. Predicting Japanese bank stock performance with a composite relative efficiency metric: A new investment tool[J].Pacific-Basin Finance Journal.2010,18(3):254-271.

[8] Meryem Duygun Fethi , Fotios Pasiouras. Assessing bank efficiency and performance with operational research and artificial intelligence techniques: A survey[J]. European Journal of Operational Research. 2010,204(2):189198.

[9] Y. H. Chen, S. C. Chen, C. L. Tsay.Business strategies in the banking industry: How to construct the most appropriate strategy by applying the BSC and AHP.[J].Journal of Statistics and Management Systems.2010,13(5): 979-1001.

[10] Chen Jiali ,LI Xuejian. A Study on Assessment for Bank Performance via PCA and AHP[J].Chinese Journal of Systems Science. 2011,19(1):74-76

[11] Yu Jie. Financial analysis of investment bank stocks [J]. Modern services. 2008,(18):204-207.

[12] Lu Pugui, Application of AHP in financial investments - choose the target Selection of investments in the A-share market bank stock.[J]. Market modernization. 2007, 31:288-289. 